\title{
PRVI KORAKI DO NOVEGA VELIKEGA \\ SLOVENSKO-MADŽARSKEGA SLOVARJA: ANALIZA \\ RELEVANTNIH DVOJEZIČNIH VIROV
}

\section{Júlia BÁLINT ČEH}

Filozofska fakulteta, Univerza v Ljubljani

Ljubljana, Slovenija

\section{Iztok KOSEM}

Filozofska fakulteta, Univerza v Ljubljani

Ljubljana, Slovenija

Bálint Čeh, J., Kosem, I. (2017): Prvi koraki do novega velikega slovensko-madžarskega slovarja: analiza relevantnih dvojezičnih virov. Slovenščina 2.o, 5 (2): 113-15o.

DOI: http://dx.doi.org/10.4312/slo2.0.2017.2.113-150.

Prispevek izhaja iz projekta snovanja novega velikega slovensko-madžarskega slovarja, pri katerem je bila za namene priprave koncepta potrebna tudi analiza obstoječih dvojezičnih virov za ta jezikovni par. Tako prispevek najprej ponudi krajši zgodovinski pregled slovensko-madžarskega slovaropisja, od prvih zbirk narečnih besed, glosarjev do frazeoloških zbirk in slovarjev. Sledi pregled dvojezičnih slovarjev za jezikovni par slovenščina-madžarščina in madžarščinaslovenščina. Prispevek se nato osredotoči na primerjavo treh najpogosteje uporabljanih slovensko-madžarskih slovarjev, in sicer slovensko-madžarskega dela slovarja Elizabete Bernjak iz leta 1995, Slovensko-madžarskega slovarja Jožeta Hradila iz leta 1996 ter slovensko-madžarskega dela Hradilovega navzkrižnega slovarja iz leta 2012. Slovarji so primerjani z vidika obsega, geslovnika, predstavitve iztočnic, zaglavja ipd. Primerjani so tudi različni elementi slovarske mikrostrukture, od prevedkov do ponazarjalnega gradiva. Opravljena je kratka študija izrazja, ki ga najdemo v e-zbirkah izrazov in ki naj bi odsevalo potrebe izobraževalnih ustanov na dvojezičnem območju. Temu sledi pregled izbranih primerov dobrih praks sodobne dvojezične leksikografije, kot je pri nas npr. Veliki angleško-slovenski slovar Oxford-DZS, v tujini pa dvojezični slovarji založb Oxford in Collins. Pri pregledu predvsem izpostavimo elemente, 
ki najbolje kažejo sodobne pristope izkoriščanja prednosti digitalnega medija in so posledično najbolj relevantni za snovanje Velikega slovensko-madžarskega slovarja.

Ključne besede: slovar, slovenščina, madžarščina, dvojezična leksikografija, koncept

\section{UVOD}

V zadnjih letih, potem ko je od prvih pobud za novi slovensko-madžarski in madžarsko-slovenski slovar minilo že osem let, ${ }^{1}$ je na področju dvojezične leksikografije za par slovenščina-madžarščina prišlo do pomembnih premikov. Od leta 2015 v Budimpešti na univerzi ELTE poteka izdelava velikega madžarsko-slovenskega slovarja, za katerega je Madžarska zagotovila sredstva do leta $2019^{2}$ in katerega načrtovani obseg je 70.000 gesel. Hkrati so se začela tudi dela na Velikem slovensko-madžarskem slovarju, in sicer v obliki ciljnega raziskovalnega projekta (dalje KOMASS),3 ki ga financira ARRS in ki poteka $\mathrm{v}$ letih 2015-2018, izvajajo pa ga Filozofska fakulteta Univerze v Ljubljani, Inštitut za narodnostna vprašanja in Filozofska fakulteta Univerze v Mariboru. $\mathrm{V}$ prispevku so tako predstavljeni podatki in razmišljanja, ki so temeljni za izdelavo zasnove novega slovensko-madžarskega slovarja.

\section{PRVE ZBIRKE NAREČNIH IN MADŽARSKIH BESED, NAREČNI IN FRAZEOLOŠKI SLOVARJI}

Prve slovensko-madžarske dvojezične zbirke besed z didaktičnim namenom segajo v 18. stoletje. Leta 1790 je za potrebe narodnostnega pouka Miklóš Küzmič v prekmurščino prevedel madžarsko slovnico $A B C$ könyvecske a Nemzeti Oskoláknak hasznokra (1778) Miklósa Révaija, razsvetljenskega jezikoslovca, književnika in univerzitetnega profesorja madžarskega jezika. $\mathrm{K}$

\footnotetext{
${ }^{1}$ Skupna izjava vlad Republike Slovenije in Madžarske s srečanja v Keszthelyu, ki je potekalo 27. novembra 2009: http://vrs-

3.vlada.si/MANDAT12/VLADNAGRADIVA.NSF/aa3872cadf1c8356c1256efboo6o3606/7aa66fc2 b526181bc1257abfoo304256/\$FILE/izjavaonamerislovar.pdf

2 http://www.uszs.gov.si/si/medijsko_sredisce/novica/archive/2015/2/browse/1/select/sporocil o_za_javnost/article/764/3092/

3 https://www.cjvt.si/komass/
} 
slovnici z naslovom $A B C$ kni'sicza je prevajalec $\mathrm{v}$ prilogi dodal kratek prekmurski-madžarski glosar z nekaj več kot 200 gesli. Leta 1833 je nato $\mathrm{v}$ Gradcu izšla madžarska slovnica $A$ magyar nyelvtudomány rövid foglalatja (1831) Imreja Szalayija v prevodu Jožefa Košiča, gornjeseniškega župnika, z naslovom Krátki návuk vogrszkoga jezika za zacsetníke (Szalay in Košič, 1833). Slovnica je izšla v prekmurščini, prevajalec je na triintridesetih straneh knjige dodal madžarsko-prekmurski glosar s približno 1500 gesli.

Leta 1919 je bil izdan madžarsko-vendski (prekmurski) slovar Aleksandra Kardoša, ki so mu sledili trije slovarji Jánosa Fliszarja: dve izdaji madžarskonarečnega slovarja (Vogrszki-vendiski rêcsnik 1922, 1942) ter narečnimadžarski slovar (Vendiski-vogrszki rêcsnik, 1943). Vsi trije Fliszarjevi slovarji so izšli v Budimpešti.

Naslednje dvojezično slovarsko delo, ki je vsebovalo narečno besedišče Porabja in Prekmurja, je izšlo šele leta 1996 v Szombathelyu, in sicer Etnološki slovar Slovencev na Madžarskem avtorice Marije Kozar, ki je izšel v 2000 izvodih. Razlagalni dvojezični slovar vsebuje več kot 300 gesel $\mathrm{v}$ abecednem redu, ki zajemajo "predmete in pojave snovne, duhovne in družbene kulture Slovencev na Madžarskem v 20. stoletju po šestintrideset tematskih skupinah« (Kozar 1996: 12).

Leta 2005 je izšel trijezični Porabsko-knjižnoslovenski-madžarski slovar Francka Mukiča, ki je s 11.000 gesli še danes najobsežnejša zbirka porabskega besedišča. Trijezični slovar je jezični relikt odrinjenega porabskega govora in filološki pripomoček (Ftičar 2006). Viri besedišča so porabski govor in ljudske pesmi. Porabske iztočnice so večinoma zapisane v gornjeseniški različici, sledi ustreznica $\mathrm{v}$ slovenskem jeziku in madžarska ustreznica ter zgledi iz vsakdanjega življenja, včasih iz svetega pisma. Iztočnica je naglašena.

Leta 2009 je v zbirki Zora izšel slovar Gornjega Senika od črke A do črke L, (Bajzek Lukač 2009). Publikacija prinaša opis samoglasniškega sistema različic podnarečij v Porabju. V knjigi najdemo kratek opis glasoslovja in oblikoslovja 
gornjeseniškega govora in besedja ter metodologije zbiranja besed. V slovarju je približno 3000 geselskih člankov. V glavi geselskega članka je navedena poknjižena narečna iztočnica in fonetični zapis, ki sledi znanstveni dialektološki transkripciji. Razlage so povzete po Slovarju slovenskega knjižnega jezika (SSKJ; Bajec idr. 1991), v geselskem članku sta navedeni še madžarska in nemška ustreznica iztočnice.

Madžarsko-slovenski frazeološki slovar Francka Mukiča iz leta 1993 vsebuje 22.00o enot, med njimi so stalni frazemi (etaloni), pregovori, izreki, biblični frazemi, glagoli s prikazom vezljivosti v obeh jezikih, madžarske samostalniške in pridevniške zloženke, ki jih v slovenščino prevedemo s predložno zvezo. Slovar vsebuje tudi številna večbesedna lastna imena (npr. zemljepisna imena, imena organizacij, naslove književnih del), izlastnoimenske pridevnike na ov/$e v$ ter citate.

V projektu EPHRAS (2006) je nastalo učno gradivo na CD-ROM-u, ki vsebuje štirijezično frazeološko podatkovno zbirko, frazeološko učno gradivo in vaje s 95 izbranimi frazemi. V frazeološki zbirki je 1000 izhodiščnih frazemov v nemškem jeziku, ki so prevedeni v slovenski, slovaški in madžarski jezik. Frazemom so dodane pomenske in slogovno-pragmatične razlage, njihova raba je ponazorjena s primeri rabe $v$ širšem sobesedilu. 4

V letih 2008-2010 je nastajala paremiološka platforma za učenje pregovorov SprichWort, 5 na kateri se nahaja petjezična podatkovna zbirka z jezikoslovno opisanimi slovenskimi, nemškimi, slovaškimi, češkimi in madžarskimi pregovori ter didaktično gradivo. Pri snovanju slovensko-madžarskega dela baze je sodelovala Elizabeta Bernjak. V slovenski podatkovni bazi pregovorov SprichWort je 212 slovenskih in 210 madžarskih pregovorov, ki so razporejeni po abecednem vrstnem redu. Platforma s pomočjo korpusno pridobljenih podatkov prikazuje tipično rabo pregovorov.

\footnotetext{
4 http://podpora.sio.si/ephras-vec\%C2\%8Djezikovno-frazeolosko-gradivo/
}

5 http://www.sprichwort-plattform.org/sp/Sprichwort_si 
Na koncu velja omeniti še e-zbirke izrazov za 15 področij, ki se poučujejo na osnovnih in srednjih šolah. E-zbirke izrazov temeljijo predvsem na učbenikih, ki se uporabljajo v dvojezičnih šolah, vsebujejo pa 29.685 enobesednih in večbesednih slovenskih izrazov in njihove prevode v madžarščini. Zbirke so nastale v okviru projekta E-kompetence učiteljev $v$ dvojezičnih šolah, ${ }^{6}$ ki sta ga financirala Evropska unija iz Evropskega socialnega sklada in Ministrstvo za izobraževanje, znanost in šport Republike Slovenije in je potekal od oktobra 2011 do avgusta 2013 pod vodstvom Zavoda za kulturo madžarske narodnosti. V projektu so sodelovali učitelji dvojezičnih osnovnih šol in srednje šole v Prekmurju, Inštitut za narodnostna vprašanja in Filozofska fakulteta Univerze v Mariboru.

\section{SODOBNI7 SLOVENSKO-MADŽARSKI IN MADŽARSKO-SLOVENSKI SLOVARJI}

Prvi madžarsko-slovenski slovar, za katerega so gradivo sestavili Franc Šebjanič, Vilko Novak in Jože Hradil, je izšel leta 1961 pri Državni založbi Slovenije. Slovensko-madžarski slovar istih avtorjev je nato izšel leta 1969, prav tako pri Državni založbi Slovenije. Oba slovarja sta imela isti cilj kot sodobni madžarsko-slovenski oz. slovenski-madžarski slovarji, tj. namenjena sta bila prebivalcem na narodnostno mešanem območju za praktično rabo. Pri izbiranju gesel so se avtorji odločali za najpomembnejše izraze (Šebjanič 1961: VI), ki so se pojavljali v tisku in govoru, pri tem so bili prepuščeni subjektivni presoji, jezikovni intuiciji in zbiranju, paberkovanju na klasičen način z ročnim izpisovanjem na kartotečne listke. Kvalitativno in kvantitativno sta bila slovarja sčasoma presežena, vendar pa avtorji veljajo za pionirje na področju slovenskomadžarskega slovaropisja.

\footnotetext{
6 http://www.e-kompetencia.si/

7 Dejansko bi tem slovarjem težko rekli sodobni, saj so nastali pred 15-20 leti. Sodoben v tem primeru tako pomeni bolj to, da je slovar široko uporabljan še danes, v tem primeru na račun dejstva, da drugih, sodobnejših dvojezičnih jezikovnih virov takšnega obsega za par slovenščina-madžarščina ni.
} 
Jože Hradil je kasneje izdal številne slovensko-madžarske in madžarskoslovenske dvojezične slovarje, pa tudi manjše večjezične slovarje. Madžarskoslovenski slovar (MASLO82) je izšel leta 1982 pri DZS v sodelovanju z Založbo Tankönyvkiadó v Budimpešti v nakladi 4000 izvodov. Slovar je bil delno zgrajen na osnovi Madžarsko-slovenskega slovarja (Šebjanič 1961) in je zahteval pet let dela. ${ }^{8}$ MASLO82 obravnava osnovno besedišče madžarskega jezika z didaktično komponento. Slovar je namenjen vsem, ki se želijo učiti madžarskega jezika oz. rešiti sporazumevalno zagato pri pisnem ali govorjenem madžarskem besedilu. Pri sestavljanju madžarskega besedišča za MASLO82 so sodelovali István Kosaras, Jože Szabó in Jože Hradil. Strokovno recenzijo je opravil dr. Vlado Peteršič. Slovar leta 2017 v knjigarnah ni več dosegljiv; zanimivo je, da so izvodi slovarja na Madžarskem poniknili že leta 1982. Založba Tankönyvkiadó je namreč takrat za madžarski trg od DZS odkupila dogovorjenih 1500 izvodov, ki pa jih potem ni prodajala in nikoli niso prišli do uporabnikov. 9

Leta 1995 sta pri Cankarjevi založbi v eni knjigi izšla madžarsko-slovenski in slovensko-madžarski slovar Elizabete Bernjak (BMSSMS95). Izdelava slovarja je trajala osem let. Pri pripravi gradiva je najprej nastal slovensko-madžarski del, po dokončanju slovensko-madžarskega dela slovarja se je založba odločila, da izda še madžarsko-slovenski del v isti knjigi. Pri pripravi madžarskoslovenskega dela slovarja so za izhodišče vzeli slovensko-madžarski del, uporabljene so bile tudi polavtomatske metode. ${ }^{10}$

Leta 1996 je Državna založba Slovenije izdala Slovensko-madžarski slovar Jožeta Hradila (SMS96), dve leti kasneje pa je pri Pomurski založbi izšel še Hradilov Madžarsko-slovenski slovar (MASLO98). Hradil je za izdelavo SMS96

\footnotetext{
8 Jože Hradil, Sorsdöntő szavak (Usodne besede), Inavguracija na Madžarski akademiji znanosti (MTA). Dostopno prek:

http://mta.hu/data/dokumentumok/szima/szekfoglalok/Hradil.pdf.

9 Jože Hradil, Sorsdöntő szavak (Usodne besede), Inavguracija na Madžarski akademiji znanosti (MTA). http://mta.hu/data/dokumentumok/szima/szekfoglalok/Hradil.pdf.

10 Podatke nam je avgusta 2017 posredovala avtorica slovarja.

(opomba se nadaljuje na naslednji strani)
} 
in MASLO98 potreboval dvanajst let. ${ }^{11}$

Omeniti velja še Madžarsko-slovenski in slovensko-madžarski evropski slovar Marjance Mihelič, ki je izšel leta 2006 pri Cankarjevi založbi v zbirki Evropskih slovarjev. Slovar je žepnega formata in vsebuje približno po 6000 iztočnic za vsak del.

Edini od omenjenih slovarjev, ki so na voljo v digitalni obliki (od leta 2006), so Hradilovi slovensko-madžarski in madžarsko-slovenski slovarji. Od leta 2006 do leta 2011 sta bila na spletni strani http://www.lingua-bridg6ge.com na voljo Madžarsko-slovenski slovar in Slovensko-madžarski slovar. Spletna slovarja sta bila na začetku na voljo registriranim uporabnikom, kasneje pa samo tistim, ki so poravnali celoletno naročnino. 28. aprila 2011 je bil dostop do obeh slovarjev ukinjen. Na to, da je bila digitalna oblika slovarja že takrat priljubljena med uporabniki, kažejo podatki o obisku strani, saj je v petih letih slovar obiskalo več kot 1700 različnih uporabnikov, opravljenih pa je bilo 742.428 iskanj. ${ }^{12}$

Od septembra 2012 je na voljo Hradilov elektronski slovensko-madžarski navzkrižni slovar (eMASLO), ki je pripravljen v obliki relacijske baze podatkov. Štirinajstdnevna preizkusna različica slovarja je dostopna na http://www.krogznak-sp.si/slovensko.php/slo-hun-slovar-szotar. Slovar je na voljo prek plačljive aplikacije (enkratna cena je 39,90 EUR), ki jo je treba namestiti na računalnik.

\subsection{Primerjava slovensko-madžarskih slovarjev}

Za potrebe projekta KOMASS smo si podrobneje primerjalno ogledali slovensko-madžarski del slovarja Elizabete Bernjak (BMSSMS95), Slovenskomadžarski slovar Jožeta Hradila iz leta 1996 (SMS96) ter slovensko-madžarski dela Hradilovega navzkrižnega slovarja (eMASLO).

Podatki o gradivnih virih in geslovnikih analiziranih slovensko-madžarskih

\footnotetext{
${ }^{11}$ Jože Hradil, Sorsdöntő szavak (Usodne besede), Inavguracija na Madžarski akademiji znanosti (MTA). http://mta.hu/data/dokumentumok/szima/szekfoglalok/Hradil.pdf. 12 Podatek je bil leta 2011 pridobljen na strani http://www.lingua-bridg6ge.com, ki pa ni več dostopna.
} 
dvojezičnih slovarjev »namiznega " obsega (Krek 2003) so precej skopi. Na splošno velja, da so bili gradivni viri za BMSSMS95 in SMS96 predvsem SSKJ, Slovenski pravopis (1994) in Slovar tujk (Verbinc 1991). Pri zbiranju gradiva in prevajanju iztočnic so si avtorji pomagali še z obstoječimi dvojezičnimi slovarji, ki so bili na voljo v devetdesetih letih. Geslovnik navzkrižnega slovarja eMASLO in vsebina posameznih geselskih sestavkov so skoraj identični z vsebino tiskanih slovarjev SMS96 in MASLO98, kar kaže, da je bila slovarska baza SMS96 prevzeta kot gradivni vir za slovensko-madžarski del eMASLO. Nikjer v omenjenih treh slovarjih ni podanih kriterijev za izbor iztočnic, manjka tudi podrobna predstavitev slovarske makro- in mikrostrukture.

BMSSMS95 ne ponuja podatka o številu geselskih člankov, zato lahko podamo le grobo oceno. Slovensko-madžarski del se razprostira na 432 straneh (od 613. do 1045. strani). Na eni strani je povprečno 50 iztočnic, po tem izračunu (432 x 50) vsebuje ta del slovarja približno 22.000 geselskih člankov. Število iztočnic v BMSSMS95 je dejansko najbrž precej večje, vendar pa štetje otežuje dejstvo, da so nemalokrat leksemi z istim korenom, tj. besedna družina, združeni v istem geselskem članku, npr.

Francija -e ž Franciaország; Francóz-a m francia; francoski-a -o francia

Posebnost BMSSMS95 je tudi to, da je pri številnih iztočnicah osnova, ki z dodatnim priponskim obrazilom, navedenem $\mathrm{v}$ drugem delu geselskega članka, postane besedotvorna podstava tvorjenke, posebej izpostavljena z rezajem, npr.

$$
\text { jézer|o } s \text { tó; sláno } \sim \text { sóstó; umétno } \sim \text { mesterséges tó; ski -a -o tó-, tavi }
$$

SMS96 Jožeta Hradila vsebuje približno 40.000 gesel (in okrog 60.00o drugih slovarskih podatkov ter izrazov), torej je po obsegu precej večji od BMSSMS95. Podobno število gesel (37.908) najdemo tudi v slovensko-madžarskem delu eMASLO. Za ponazoritev ponujamo primerjavo gesel od $m$ do makaron. Rdeče obarvane iztočnice najdemo v vseh treh slovarjih, črno obarvane samo v obeh Hradilovih slovarjih (torej ne v BMSSMS95), podčrtana je iztočnica $m$, ki jo najdemo samo v SMS96, medtem ko iztočnice v krepkem tisku najdemo samo 
v BMSSMS95. Že samo ta kratka primerjava pokaže razlike v obsegu slovarjev, pa tudi neenoten nabor kriterijev za vključitev iztočnic $\mathrm{v}$ slovar. $\mathrm{Z}$ vidika jezikovnega para je dokaj zanimivo, da v BMSSMS95 ne najdemo iztočnice madžarščina:

m, mácelj, macerácija, macerírati, macêsen, macêsnov, macesovína, macóla, mačè, máčeha, máčehovski, máček, mačéta, máčica, máčji, máčka, máčkast, máčkin, madáma, madéira, mádež, mádežast, madison, madóna, Madrídčan madrigál, madrónščina, Madžár, madžariti, madžárizírati, madžarón, madžarónski, Mádžarska, madžárski, madžárstvo, madžárščina, maestrál, maéstro, máfija, mág, magacín, magazín, magazinêr, Magdaléna, mágičen, mágija, magíster, magistrála, magistrale, magistrálen, magistrálen, magistrát, magistráten, magistratúra, magistrírati, magistrski, mágma, mágna kárta, magnát, magnét, magnéeten, magnétičnost, magnetít, magnetízem, magnetizêr, magnetiziranje, magnetizírati, magnétnica, magnetofón, magnetofónski, magnetométer, magnetoskóp, magnetoskópski, magnétovec, magnetrón, magnézij, magnézija, magnézijev, magnezít, magnificénca, magnifikát, magnifikus, magnólija, magót, màh, máh, mahagóni, mahagónijev, maharádža, máhast, máhati, mahedráti, mahedráv, mahedrávke, mahedrávost, mahinácija, mahljáti, máhniti, máhoma, máhovec, mahovína, mahóvje, máhovka, mahóvnica, mahovnják, máj, mája, majarón, májati, majàv, majávost, májcen, májčken, majestéta, majestétičen, májhen, májhnost, májica, majílnik, majíti, majólika, majonéza, majór, majorát, majoritéta, majorizírati, majórski, májski, majúskula, màk, makadám, makadamizirati, makadámski, makák, makarón

BMSSMS95, SMS96 in eMASLO zajemajo občnoimensko besedišče polnopomenskih besed (samostalniške besede, pridevniške besede, glagole in prislove) ter funkcijske besedne vrste (predlogi, vezniki, medmeti, členki). Prevladujejo enobesedne iztočnice, večbesedne so redke. V SMS96 in eMASLO so večbesedne iztočnice nekatere tujke npr. a priori, a propos, call girl, camera obscura, v BMSMS95 teh večbesednih iztočnic ni. Po drugi strani v BMSSMS95 med iztočnicami najdemo zveze tipa ucvreti jo. Med večbesednimi iztočnicami najdemo tudi glagole s prostim morfemom se/si (npr. bahati se, bati se, nalesti se), pri čemer izbira tovrstnih iztočnic sledi SSKJ.

Vsi trije slovarji vsebujejo tudi lastnoimenske iztočnice, torej osebna, zemljepisna in stvarna lastna imena, od katerih prevladujujejo osebna imena, imena pripadnikov narodov in narodnosti ali držav, imena celin, nekaterih držav in mest (gl. Tabelo $6 \mathrm{v}$ Prilogi za primerjalni pregled zemljepisnih lastnih 
imen, ki se začnejo s črko B). Stvarnih imen, npr. naslovov umetnostnih in neumetnostnih besedil, ki so velikokrat večbesedna (Brižinski spomeniki, Osimski sporazumi), skladb, arhitekturnih stvaritev, imen organizacij in družbenih teles ter ustanov na ravni iztočnic ne najdemo; če so že podana, jih najdemo v ponazarjalnem gradivu, npr. Organizacija združenih narodov je v vseh treh slovarjih navedena v geslu samostalnika narod. Glede na izhodiščni jezik je pomenljivo, da iztočnice Slovenec v SMS96 in eMASLO ni, v BMSSMS95 pa je navedena v geselskem članku Slovenija. Splošno gledano, vsi trije analizirani slovarji vsebujejo skromno število najbolj pogostih ali kulturološko zanimivih (Bálint Čeh 2013) lastnih imen, ki so dejansko še kako relevantna za uporabnike, saj se pravila zapisa lastnih imen v slovenščini in madžarščini močno razlikujejo.

BMSSMS95, SMS96 in eMASLO vsebujejo tudi številne strokovne izraze. Vzorčna analiza vseh iztočnic s terminološko oznako pod črko B (od bacil do burjevka) v treh slovarjih (Tabela $7 \mathrm{v}$ Prilogi) razkrije, da je v SMS96 in eMASLO večje število strokovnih izrazov z različnih področij kot v BMSSMS95, kar je tudi posledica dejstva, da je BMSSMS95 po obsegu najmanjši od treh slovarjev in so zaradi praviloma redkejše rabe v jeziku strokovni izrazi nižje na seznamu prioritet pri izbiri geslovnika. Pri geslih, ki jih najdemo v vseh treh slovarjih, opazimo pogostejšo uporabo področnih oznak v SMS96 in eMASLO kot v BMSSMS95 za besede, ki so že del splošnega jezika (npr. bacil, beljakovina, beluš).

Kot referenčno gradivo za zapis in naglaševanje iztočnic v primerjanih slovarjih sta bila uporabljena predvsem Slovenski pravopis (1990) in SSKJ, vendar pa najdemo tudi primere odstopanj, zlasti v SMS96 in eMASLO, pri katerih je uporabljen zapis iz terminološkega slovarja, ki je služil kot vir za iztočnico. V SMS96 in na njem temelječem eMASLO so tako izlastnoimenski vrstni pridevniki s priponskimi obrazili -ov/-ev napisani z veliko začetnico, npr. medicinski izrazi, kot so Adamovo jabolko pod iztočnico ádámcsutka, Evstahijeva cev kot slovenska iztočnica ter tudi kot ekvivalent madžarski 
iztočnici Eustach-kürt v MASLO98 sledijo zapisu v Pravopisu medicinskih izrazov (Kališnik 1997), čeprav Slovenski pravopis (1994) v tovrstnih primerih priporoča malo začetnico.

V BMSSMS95 in SMS96 so iztočnice opremljene z naglasi, kar je v veliko pomoč zlasti madžarskemu uporabniku. V eMASLO za razliko od tiskanega predhodnika SMS96 ni naglasnih znamenj na slovenskih iztočnicah, kar je nenavadna odločitev glede na to, da eMASLO ne ponudi alternative, npr. posnetkov izgovorjave. Zanimivo je še, da so v BMSSMS95 naglašene tudi slovenske besede znotraj geselskih člankov, npr. v zgledih rabe (báti $s e \rightarrow$ bojím se za življênje).

Pri obravnavi homonimov (Bálint 1997: 17) so razlike med slovarji predvsem v načinu označevanja iztočnic. Tako so v SMS96 homonimne iztočnice zaznamovane $\mathrm{z}$ nadpisano številko za iztočnico, v eMASLO jih označuje številka, BMSSMS95 pa ne uporablja posebnih elementov za njihovo razločevanje (gl. npr. Tabelo 1). 


\begin{tabular}{|c|c|c|}
\hline BMSSMS95 & SMS96 & eMASLO \\
\hline $\begin{array}{l}\text { kós -a m rigó; čŕni (zoo.) } \\
\text { feketerigó } \\
\text { kós -a m darab, rész; za } \\
\text { kósom darabonként; po } \\
\text { kósih minden darabot külön- } \\
\text { külön } \\
\text { kós (prisl) } \\
\text { megfelelően/méltányosan } \\
\text { teszi a dolgot; ne bíti kómu } \\
\text { nem ér fel vele; ne bíti čému } \\
\sim \text { nem tud elintézni vmit }\end{array}$ & $\begin{array}{l}\text { kós biti čemu } \\
\text { megfelel vminek, } \\
\text { megbirkózik vmivel; } \\
\text { biti položaju } \\
\text { megállja a helyét } \\
\text { kós' m (ptica) rigó } \\
\text { kós² del snovi, stvari } \\
\text { darab; kupil je kruha } \\
\text { megvett egy darab } \\
\text { kenyeret; šla sta } \\
\text { skupaj velik poti jó } \\
\text { darabot mentek együtt; } \\
\text { ulit kot iz enega } \sim a \text { egy } \\
\text { darabból öntve }\end{array}$ & 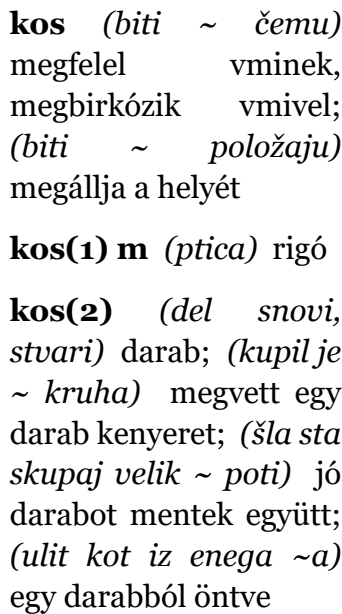 \\
\hline
\end{tabular}

Tabela 1: Homonimne iztočnice kos v treh slovensko-madžarskih slovarjih.

V primerih, kjer prihaja do pomenskih osamosvojitev, kot npr. pri iztočnici kos (Tabela 1) v povedni rabi z dajalnikom v zvezi z biti kos komu/čemu, je osamosvojena povedkovniška pozicija (Vidovič Muha 2000) v vseh treh slovarjih obravnavana pod samostojno iztočnico (samo BMSSMS95 nudi informacijo o besedni vrsti), vendar ne kot homonim ali frazeološka enota.

V vseh treh slovarjih se pojavljajo homonimni pari tudi znotraj istega geselskega članka, npr. átlas in bòr, kar odstopa od pristopa, ki ga uporablja SSKJ, na katerem naj bi slovarji temeljili. V SMS96 in eMASLO sta tako pomena 'zbirka zemljevidov' in 'svilena tkanina' oziroma 'iglasto drevo' in 'kemijski element' ločena z arabskimi številkami, medtem ko je v BMSSM95 naveden samo en pomen pri iztočnici atlas, različna pomena pri iztočnici bòr pa sta ločena s podpičjem. Pri nekaterih homonimnih parih je vključena $\mathrm{v}$ slovar samo ena homonimna beseda, npr. péč v pomenu 'naprava za ogrevanje', $\mathrm{v}$ vseh treh slovarjih pa manjka péč v pomenu 'skala'.

Vsi trije slovarji ponujajo informacijo o spolu samostalnika v obliki krajšave, 
vendar pa jo BMSSMS95 ponudi v slovenščini (m, ž, s), SMS96 in eMASLO pa $\mathrm{v}$ madžarščini ( $\mathrm{m}, \mathrm{f}, \mathrm{n})$. $\mathrm{V}$ vseh treh slovensko-madžarskih slovarjih neštevni edninski samostalniki (npr. kri, mladina, upanje) niso posebej označeni. Množinski samostalniki (bínkošti, hláče, jétra, saní, vráta) so navedeni v množinskih oblikah in opremljeni z oznakama za spol in množinski samostalnik ( $p l$ in $m n$ ).

Glagoli so navedeni v nedoločniku v iztočnici, prevodna ustreznica oz. prevodne ustreznice v madžarščini pa so navedene v 3. osebi ednine. BMSSMS95 v zaglavju navaja še prvoosebno obliko ednine v sedanjiku. Glagolska vezljivost je ponazorjena z zgledi v geselskem članku samo pri temeljnih glagolih stanja (biti, imeti), dejanja in procesov.

V BMSSMS95 so pri pridevnikih navedene osnovne oblike vseh treh sklonov, npr. dóber, dôbra -o. Nepregibni pridevniki so označeni z oznako neskl., npr. pocéni neskl. V SMS96 in eMASLO je ponujena samo tipična slovarska oblika pridevnika, torej v moškem spolu v imenovalniku ednine.

V vseh treh slovarjih zasledimo nekaj predložnih gesel, npr. brez, iz, na, pri, proti, $v$, pri čemer so predložna gesla v BMSSMS95 v primerjavi s SMS96 in eMASLO precej manj podatkovno bogata; po drugi strani je BMSSMS95 edini, ki ponuja informacijo o besedni vrsti (gl. Tabelo 2).

\begin{tabular}{|c|c|c|}
\hline BMSSMS95 & SMS96 & eMASLO \\
\hline $\begin{array}{l}\text { na predl.-ra, -re; on, -en, - } \\
\text { ön; tó ezután; 〜 vès } \\
\text { glás torkaszakadtából ; } \\
\text { pomóč! segítség! nóge } \\
\text { felkelni! gyerünk! indulj! }\end{array}$ & $\begin{array}{l}\text { na -ra, -re; } \sim \text { glavo } \\
\text { fejre; hišo házra; } \\
\text { noge talpra; njegovo } \\
\text { roko kezére; moje ime } \\
\text { az én nevemre; 2. -on, - } \\
\text { en, -ön; polju mezőn; } \\
\text { misliti prihodnost } \\
\text { jövőre gondol; stati } \\
\text { glavi fején áll; } \sim \\
\text { pokopališč temetőben; } \\
\sim \text { pogrebu temetésen; } \\
\text { vidim ga enkrat leto } \\
\text { évente egyszer látom; }\end{array}$ & $\begin{array}{l}\text { na -ra, -re; ( glavo) } \\
\text { fejre; ( hišo) házra; }(\sim \\
\text { noge) talpra; }(\sim \text { njegovo } \\
\text { roko) kezére; }(\sim \text { moje } \\
\text { ime) az én nevemre; 2. - } \\
\text { on, -en, -ön; } \quad(\sim \text { polju) } \\
\text { mezőn; (misliti } \sim \\
\text { prihodnost) } \\
\text { gondol; (stati } \sim \text { glavőre } \\
\text { fején áll; ( pokopališč }) \\
\text { temetóben; ( pogrebu) } \\
\text { temetésen; (vidim ga } \\
\text { enkrat } \sim \text { leto) évente }\end{array}$ \\
\hline
\end{tabular}




\begin{tabular}{|c|c|c|}
\hline & $\begin{array}{l}\text { tvoje } \\
\text { egészségedre! }\end{array}$ & $\begin{array}{l}\text { egyszer látom; ( tvoje } \\
\text { zdravje!) egészségedre! }\end{array}$ \\
\hline iz predl. -ból, -ből & $\begin{array}{l}\text { iz -ból, ból; pogledalje } \\
\text { hiše kinézett a házból; } \\
\text { zloba gleda njegovih } \\
\text { oči gonoszság sugárzik a } \\
\text { szeméból }\end{array}$ & $\begin{array}{l}\text { iz -ból, ből; (pogledal je } \\
\text { hiše) kinézett a házból; } \\
\text { (zloba gleda njegovih } \\
\text { oči) gonoszság sugárzik a } \\
\text { szeméból }\end{array}$ \\
\hline $\begin{array}{l}\text { v predl. -ba, -be; -ban, - } \\
\text { ben; -ból, -ből; befelé, } \\
\text { be(lé) }\end{array}$ & $\begin{array}{l}\mathbf{v} \text {-ba, -be, -ban, -ben; } \\
\text { tem abban; tistega } \\
\text { abba; tisto smer abba } \\
\text { az irányba; grem } \sim \\
\text { Maribor Mariborba } \\
\text { megyek; } \sim \text { Mariboru sem } \\
\text { Mariborban vagyok; } \\
\text { hiši živeti házban él }\end{array}$ & 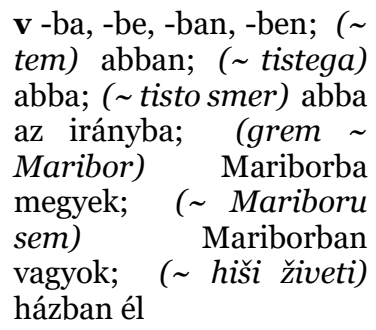 \\
\hline
\end{tabular}

Tabela 2: Geselski članki predlogov $n a$, iz in $v$ v treh slovensko-madžarskih slovarjih.

Prevedki so v BMSSMS95, SMS96 in eMASLO med seboj ločeni z vejico, za manjše pomenske odmike med prevedki oz. nizi prevedkov pa se uporablja tudi podpičje, npr.

úpanje $\mathbf{n}$ remény, reménység, bizakodás; kilátás; $v \sim u$, da... annak reményében, hogy... zbuditi reményt ébreszt (vir: SMS96)

V SMS96 in eMASLO so znotraj geselskega članka različni pomeni označeni z arabskimi številkami, npr.

délati 1. dolgozik; kot črna živina rogyásig dolgozik; na svojo roko saját felelőségére teszi 2. (stroj) müködik; tale stroj ne dela več ez a gép már nem müködik (vir: SMS96)

V določenih primerih so za številko pomena v oklepaju navedeni pomenski indikatorji (glej 2. pomen pri delati), kot so nadpomenke, kolokacije, oblike (npr. glagol s prostim morfemom se) ipd. Indikatorje najdemo tudi pri enopomenskih geslih, predvsem pri redkejših in predvidoma uporabnikom manj znanih besedah, npr. 
krvavec m (krvnik) hóhér （vir: eMASLO)

Ponazarjalno gradivo je od prevedkov ločeno s podpičjem. Pregled naključnih gesel je pokazal, da je količina ponazarjalnega gradiva nekako sorazmerna $\mathrm{s}$ pogostostjo iztočnice, tj. pogostejše iztočnice ga imajo več, redkejše pa manj ali celo nič (ponujeni so samo prevedki). Poleg tega imata SMS96 in eMASLO praviloma nekoliko več ponazarjalnega gradiva na geslo od BMSSMS95.

Ponazarjalno gradivo v slovarjih vsebuje različne kategorije večbesednih nizov, od kolokacij, stalnih zvez, daljših ustaljenih besednih nizov ipd. pa do zgledov rabe in frazemov, vendar pa kategorije v geslih niso jasno ločene oz. so pogosto celo pomešane (gl. spodaj primer za beseda). To je za uporabnika precej neprijazna rešitev, saj bi recimo ločen razdelek s frazeološkimi enotami (kot je praksa v sodobnih virih) jasno opozoril uporabnika, da gre za vsebino $\mathrm{z}$ netransparentnim pomenom. Na ta način bi se izognili tudi zavajanju uporabnikov, da so frazemi, navedeni med ostalim gradivom, povezani z enim ali več pomeni iztočnice.

\section{beséda}

o dati obljubiti komu kaj szavát adja

o držati megtartja a szavát

prijeti za o szaván fog vkit

do $\sim$ e priti szóhoz jut

ni vredno e szóra sem érdemes

z eno o száz szónak is egy a vége

ne najti $\sim e$ nem talál szavakat

ne spregovoriti niti ene same ice egy árva szót sem szól

prositi za o szót kér

on ima o övé a szó

častno o dati (becsület) szavát adja

prazne $\sim e$ üres szavak

prelomiti o adott szavát megszegi (vir: SMS96) 
Kot je razvidno iz zgornjega primera za geslo beseda, najdemo v ponazarjalnem gradivu tudi pojasnila, npr. obljubiti komu kaj za kolokacijo besedo dati, ki so v slovenščini in imajo posledično večjo uporabno vrednost za rojene govorce slovenščine, ki slovar uporabljajo pri jezikovni produkciji v madžarščini.

Frazemi so v slovarjih običajno navedeni pri pomenotvorni sestavini frazema (npr. dobro blago se samo hvali najdemo v eMASLO pri dober in blago) ali pri prvi polnopomenski besedi, ki jo vsebujejo. Frazemi, razen pregovorov, velikokrat niso navedeni v leksikalno nevtralni (slovarski) obliki, ampak kot zgled, npr. v SMS96 in eMASLO pod iztočnico maslo najdemo to je njegovo maslo 'ebben az ő keze van benne', kar je uporabniku bolj prijazno od abstraktnejše nevtralne oblike.

Zgledov rabe je sicer v vseh treh slovarjih dokaj malo, v večini primerov pa gre za iztržke in ne povedi. Praviloma so zgledi zapisani z malo začetnico in brez končnega ločila, razen tistih, ki se končajo s klicajem ali vprašajem.

\subsection{Analiza e-zbirk izrazov}

Kot smo izpostavili $\mathrm{v}$ prejšnjem razdelku, obstoječi slovensko-madžarski slovarji po obsegu ne dosegajo velikih dvojezičnih slovarjev, ob tem pa se postavlja vprašanje, kateri del besedišča dejansko pokrivajo. Namreč, če je glavni cilj slovarjev zadovoljiti potrebe uporabnikov na narodnostno mešanem območju, bi pričakovali, da bo pokrito predvsem besedišče iz splošnega jezika in terminološki izrazi, ki se pogosto uporabljajo v vsakdanjem življenju, npr. v izobraževanju, javnih uradih, pri storitvah (banke, pošta ipd.). Zlasti izobraževalna sfera, tako učitelji kot učenci, so pogosto omenjeni ciljni uporabniki slovensko-madžarskih in madžarsko-slovenskih slovarjev. Tudi pri projektu KOMASS se bo pri snovanju slovarja oz. bolje rečeno slovarske baze moralo upoštevati potrebe učiteljev v dvojezičnih šolah. Posledično so e-zbirke izrazov, ${ }^{13}$ ki so nastale pri projektu E-kompetence učiteljev $v$ dvojezičnih šolah,

13 http://eslovar.datadev.si/ 
precej pomemben jezikovni vir, saj so po eni strani najsodobnejši dvojezični vir za par slovenščina-madžarščina, po drugi strani pa dober pokazatelj predvsem terminoloških, pa tudi splošnih, potreb uporabnikov v izobraževanju na dvojezičnem območju.

Iz tega razloga smo se odločili za dve analizi: a) preveriti zastopanost iztočnic iz e-zbirk izrazov v referenčnem korpusu za slovenščino, kar naj bi pokazalo, slovar kakšnega obsega bi dejansko zadovoljil potrebe šolskih uporabnikov (in tudi, do kakšne mere lahko potrebe šolskih uporabnikov zadovoljijo obstoječi slovarji), in b) opraviti primerjavo pokritosti iztočnic iz e-zbirk izrazov v enem od slovensko-madžarskih slovarjev, tj. eMASLO. Za potrebe analize smo najprej pripravili izbor enobesednih iztočnic iz e-zbirk izrazov (od tu naprej eIzrazi). Od skupaj 11.970 iztočnic jih je 8079 enobesednih že v e-zbirkah izrazov, 3891 pa smo jih dodali iz večbesednih iztočnic (npr. iz večbesednih iztočnic aktivna socialna politika in aktivni počitek smo za enobesedne iztočnice uporabili aktiven in socialen; politika in počitek sta bili že med obstoječimi enobesednimi iztočnicami).

\subsubsection{EIZRAZI IN GIGAFIDA}

Pogostost vsake iztočnice v eIzrazih smo preverili v Gigafidi, referenčnem korpusu za slovenščino (Logar Berginc idr. 2012), 14 pri čemer smo iztočnice razvrstili v devet različnih razredov glede na mesto na frekvenčnem seznamu lem (Tabela 3). Iz Tabele 3 je razvidno, da je porazdelitev iztočnic v eIzrazi precej enakomerna: precej jih je sicer dokaj redkih (iztočnice nad 50.000 mestom na frekvenčnem seznamu imajo v korpusu 552 pojavitev ali manj), po drugi strani pa jih je precej tudi zelo pogostih (iztočnice do 10.000 mesta na seznamu imajo v korpusu 8413 pojavitev ali več). Precej je tudi pogostejšega besedišča, saj je skoraj $35 \%$ iztočnic $\mathrm{v}$ eIzrazi med prvimi 15.000 najpogostejšimi lemami v referenčnem korpusu Gigafida. Razporeditev besednih vrst je po frekvenčnih razredih dokaj enakomerna: samostalniki 
predstavljajo med 66 in $74 \%$ iztočnic v posameznem razredu, pridevniki med 18 in $26 \%$, glagoli med 1 in $7 \%$, prislovi med 1 in $6 \%$, medtem ko je, sicer zelo skromna, zastopanost ostalih besednih vrst (predlogi, števniki, zaimki in členki) omejena predvsem na frekvence do 10.000 .

\begin{tabular}{|c|c|c|}
\hline $\begin{array}{l}\text { Frekvenčni } \quad \text { razred } \\
\text { (Gigafida) }\end{array}$ & $\begin{array}{l}\text { Število iztočnic } \\
\text { v eIzrazih }\end{array}$ & $\begin{array}{l}\text { Odstotek } \\
\text { iztočnic } \\
\text { eIzrazih }\end{array}$ \\
\hline Prvih 1000 lem & 617 & 5,2 \\
\hline $1000-5000$ & 1971 & 16,5 \\
\hline 5000-10.000 & 1529 & 12,8 \\
\hline $10.000-15.000$ & 1061 & 8,9 \\
\hline $15.000-20.000$ & 795 & 6,7 \\
\hline $20.000-30.000$ & 1080 & $9 \%$ \\
\hline $30.000-40.000$ & 725 & 6,1 \\
\hline $40.000-50.000$ & 522 & 4,4 \\
\hline $50.000-$ & 3389 & 28 \\
\hline ni pojavitve v korpusu & 281 & 2,4 \\
\hline SKUPAJ & 11.970 & \\
\hline
\end{tabular}

Tabela 3: Število iztočnic v eIzrazih glede na frekvenčni razred v korpusu Gigafida.

Analiza je tako pokazala, da učitelji oz. šolski uporabniki z vidika potreb besedišča, ki naj bi ga dvojezični slovensko-madžarski slovarji pokrivali, dejansko sodijo med zahtevnejše uporabnike. Pri poučevanju oz. učenju se namreč srečujejo tako s pogostim kot precej redkim besediščem v slovenskem jeziku. Tako do 40.000 gesel, kot jih najdemo $\mathrm{v}$ obstoječih slovenskomadžarskih slovarjih, precej verjetno ne more uspešno zadovoljiti vseh potreb uporabnikov, saj ne pokrijejo ne pogostejšega (in osnovnega) ne redkejšega besedišča, ki je večinoma terminološke narave, v zadovoljivi meri. To tezo smo 
se odločili preveriti z iskanjem eIzrazov v eMASLO.

\subsubsection{EIZRAZI IN EMASLO}

eMASLO sicer od primerjanih treh slovensko-madžarskih slovarjev resda ni največji (zgolj nekaj tisoč iztočnic več ima SMS96), je pa edini v elektronski obliki, kar je deloma olajšalo postopek iskanja (vseeno je bilo treba vsako iskanje opraviti ročno). Zanimalo nas je predvsem, kolikšen delež iztočnic v eIzrazih najdemo v eMASLO. Rezultati so predstavljeni v Tabeli 4 in kažejo naslednje: od 11.970 iztočnic jih 7731 najdemo v eMASLO, kar 4239 (več kot 35 \%) pa ne. Pričakovano delež iztočnic, ki jih ne najdemo v eMASLO, narašča s padanjem njihove pogostosti v korpusu Gigafida. Izjema so le iztočnice med 5.000. in 10.000. mestom na frekvenčnem seznamu, kjer je delež manjkajočih dokaj visok: $17,9 \%$.

\begin{tabular}{|c|c|c|c|}
\hline $\begin{array}{l}\text { Frekvenčni } \\
\text { razred } \quad \text { v } \\
\text { korpusu } \\
\text { Gigafida }\end{array}$ & $\begin{array}{l}\text { Število } \\
\text { iztočnic } \\
\text { v } \\
\text { eIzrazih, } \\
\text { ki niso v } \\
\text { eMASLO }\end{array}$ & $\begin{array}{l}\text { Odstotek od } \\
\text { vseh iztočnic } \\
\text { eIzrazov v } \\
\text { frekvenčnem } \\
\text { razredu }\end{array}$ & Primeri iztočnic \\
\hline Prvih 1000 lem & 28 & 4,5 & $\begin{array}{l}\text { čisto, članica, lepo, očitno, } \\
\text { osnoven, raziskava, reden, } \\
\text { smrt, spleten, težko }\end{array}$ \\
\hline $1000-5000$ & 189 & 9,6 & $\begin{array}{l}\text { aktualno, bistveno, čestitika, } \\
\text { datoteka, globoko, grozdje, } \\
\text { konkurenčnost, naslovnica, } \\
\text { regïjski, saden, uveljavljen, } \\
\text { vložen }\end{array}$ \\
\hline 5000-10.000 & 273 & 17,9 & $\begin{array}{l}\text { alergija, brskalnik, cikel, } \\
\text { direktorat, iskan, kazalnik, } \\
\text { kmetovanje, kroven, opomba, } \\
\text { posodobitev, preiskovati, strm }\end{array}$ \\
\hline
\end{tabular}




\begin{tabular}{|c|c|c|c|}
\hline $10.000-15.000$ & 211 & 8,9 & $\begin{array}{l}\text { akustičen, alergičen, dlančnik, } \\
\text { dramatika, izkoristek, } \\
\text { lahkotno, odbïati, odziven, } \\
\text { posvojitev, poudarjeno }\end{array}$ \\
\hline $15.000-20.000$ & 191 & 20 & $\begin{array}{l}\text { enostransko, evidentirati, } \\
\text { interdisciplinaren, kazalo, } \\
\text { nadstandarden, podcenjen, } \\
\text { sklonjen, usklajeno }\end{array}$ \\
\hline $20.000-30.000$ & 314 & 29 & $\begin{array}{l}\text { berljiv, členitev, digitalizacija, } \\
\text { izpisovati, krvodajalstvo, } \\
\text { likviden, odrivati, protisloven }\end{array}$ \\
\hline $30.000-40.000$ & 242 & 33,4 & $\begin{array}{l}\text { anuiteta, cepitev, časovnica, } \\
\text { hiperaktiven, intranet, } \\
\text { knjiženje, kolebnica, odčitati, } \\
\text { otožno, postopnost }\end{array}$ \\
\hline $40.000-50.000$ & 208 & 40 & $\begin{array}{l}\text { absorpcijski, dekodiranje, } \\
\text { intervalen, kondenzacijski, } \\
\text { lomljen, monotono, } \\
\text { okoljevarstvo, raztegovanje, } \\
\text { simetrično }\end{array}$ \\
\hline $50.000-$ & 2313 & 68,3 & $\begin{array}{l}\text { ažuriranje, citiranost, } \\
\text { etnografija, gajica, izohipsa, } \\
\text { krajšava, ograditev, tlakomer }\end{array}$ \\
\hline $\begin{array}{l}\text { ni pojavitve v } \\
\text { korpusu }\end{array}$ & 270 & 96 & $\begin{array}{l}\text { diatonija, izočrta, kapacizem, } \\
\text { opistograf, samoindukcija }\end{array}$ \\
\hline SKUPAJ & 4239 & & \\
\hline
\end{tabular}

Tabela 4: Število iztočnic iz eIzrazov, ki jih ne najdemo v eMASLO.

Če pogledamo besednovrstno razporeditev iztočnic, ki jih ne najdemo v eMASLO (Tabela 5),15 vidimo, da s padajočo frekvenco narašča delež

${ }_{15}$ Seštevek odstotkov za posamezni frekvenčni razred ni vedno 100 \%, ker so v tabeli navedene samo štiri polnopomenske besedne vrste. 
samostalnikov, kar je pričakovano, saj je delež samostalnikov pri redkejših iztočnicah višji (tako v korpusu kot v našem izboru). Opazen je tudi precej visok delež pridevnikov in zlasti prislovov; pri slednjih sploh glede na njihov nizek delež po frekvenčnih razredih.

\begin{tabular}{|c|c|c|c|c|}
\hline $\begin{array}{l}\text { Frekvenčni } \\
\text { razred }\end{array}$ & $\begin{array}{l}\text { samostalniki } \\
\text { v odstotkih }\end{array}$ & $\begin{array}{l}\text { pridevniki } \\
\text { v } \\
\text { odstotkih }\end{array}$ & $\begin{array}{l}\text { glagoli v } \\
\text { odstotkih }\end{array}$ & $\begin{array}{l}\text { prislovi v } \\
\text { odstotkih }\end{array}$ \\
\hline Prvih 1000 lem & 39 & 25 & 4 & 21 \\
\hline $1000-5000$ & 46 & 35 & 3 & 16 \\
\hline 5000-10.000 & 49 & 36 & 3 & 12 \\
\hline $10.000-15.000$ & 55 & 36 & $\mathrm{O}$ & 8 \\
\hline $15.000-20.000$ & 61 & 34 & 1 & 5 \\
\hline 20.000-30.000 & 58 & 34 & 2 & 6 \\
\hline $30.000-40.000$ & 60 & 34 & 2 & 4 \\
\hline $40.000-50.000$ & 62 & 35 & o & 3 \\
\hline $50.000-$ & 71 & 27 & 1 & 2 \\
\hline $\begin{array}{l}\text { ni pojavitev v } \\
\text { korpusu }\end{array}$ & 74 & 19 & 1 & 6 \\
\hline
\end{tabular}

Tabela 5: Iztočnice iz eIzrazov, ki jih ni v eMASLO, po besednih vrstah.

Pregled iztočnic, ki jih ni v eMASLO, tudi pokaže, da ne gre zgolj za nove koncepte (npr. datoteka, brskalnik), kar bi sicer zaradi datuma izdelave obstoječih slovensko-madžarskih slovarjev pričakovali, ampak tudi za precej (pogosto) vsakdanje besedišče, ki nikakor ni novo (npr. raziskava, smrt, alergija), pa pogosto tudi ne specifično za izobraževalne situacije. Splošno gledano to še bolj izpostavlja potrebo po slovensko-madžarskem slovarju velikega obsega. 


\section{SODOBNA DVOJEZIČNA LEKSIKOGRAFIJA: DOBRE PRAKSE}

Obstoječi slovensko-madžarski slovarji tudi zaradi številnih korenitih sprememb v leksikografskih pristopih v zadnjih desetletjih, do katerih je prišlo predvsem na račun razmaha digitalnih tehnologij, pa tudi zaradi potreb sodobnih slovarskih uporabnikov, tako človeških kot računalniških, niso najboljši temelj za snovanje novega velikega slovensko-madžarskega slovarja. V tem razdelku se tako osredotočamo na tri sodobne dvojezične vire in pristope, ki ponujajo rešitve, katerim bi bilo smiselno slediti pri snovanju novega slovensko-madžarskega slovarja, pa tudi pri snovanju ostalih dvojezičnih slovarjev v slovenskem prostoru.

Od izdaje Velikega angleško-slovenskega slovarja Oxford-DZS (Krek 2005/2006) je sicer minilo že več kot 10 let, vendar še danes s 120.000 iztočnicami predstavlja najsodobnejši in največji dosežek slovenske dvojezične leksikografije. Slovar se od predhodnikov razlikuje predvsem v bogatosti informacij v slovarskih geslih, njihovi strukturiranosti, npr. uporabi razdelkov Posebne zveze, Idiomi, pri glagolih tudi Sestavljeni glagoli), pa tudi z vidika podajanja ponazoritvenega gradiva od kontrastivno bolj jasnih (npr. kjer je $\mathrm{v}$ zgledu uporabljen eden od prevedkov) do manj jasnih primerov (kjer je prevodna rešitev povsem drugačna). Pomemben element slovarja je tudi metodologija, in sicer dosledna uporaba korpusnega pristopa, tako pri izbiri angleškega geslovnika kot pri preverjanju slovenskih prevodov. Vendar pa slovar ni bil zasnovan za spletni medij, kar pa velja tudi za vse obstoječe dvojezične slovarje, pri katerih je eden od jezikov slovenščina; posledično je primere dobre prakse $\mathrm{v}$ tem segmentu treba iskati v tujini.

Založbi Oxford in Collins sta že od nekdaj sinonima za inovacije v (dvojezični) leksikografiji. Kot primera dobre prakse tu navajamo angleško-španska slovarja obeh založb, ${ }^{16} \mathrm{v}$ katerih velja izpostaviti predvsem sledeče prakse in

\footnotetext{
${ }_{16}$ Dostopna na https://es.oxforddictionaries.com/ (Oxford) in
} https://www.collinsdictionary.com/ (Collins). 
vsebine:

- Bogatejše in strukturirano ponazoritveno gradivo. V tem pogledu izstopa slovar založbe Collins, ki kolokacije, iztržke in celostavčne zglede ločuje od frazemov - le ti so namreč jasno ločeni od ostale vsebine tako, da je pred njimi vedno naslov »Idiom « -, poleg tega pa jih tudi pogosto združuje pod izbrano krovno obliko, npr. pod in a word najdemo in other words, in the words of Calderón, in his own words in she didn't say so in so many words. Količina ponazoritvenega gradiva je res občudovanja vredna, npr. pri samostalniku word ('beseda'), ki ima v slovarju sedem pomenov, najdemo 90 enot, od tega 7 idiomov.

Po drugi strani je ponazoritveno gradivo v slovarju Oxford le občasno strukturirano, kot je npr. pri prvem pomenu za samostalnik house, kjer so primeri pridevniške rabe samostalnika podani ločeno pod razdelkom [before noun]). Je pa neke vrste strukturiranost podana $\mathrm{v}$ obliki prioritiziranja ponazarjalnega gradiva, ki ga Oxfordov slovar deli v glavno gradivo, prikazano ob odprtju gesla, in dodatno gradivo, ki je uporabniku pod posameznim (pod)pomenom dostopno s klikom na gumb More example sentences.

Še več dodatnega gradiva pa $\mathrm{v}$ obeh slovarjih predstavljajo dodatni neprevedeni celostavčni zgledi za angleške iztočnice, ki so posledično namenjeni špansko govorečim govorcem za razumevanje in uporabo angleških besed. Takšno uporabo zgolj zgledov ciljnega jezika (z izjemo zahtevnejših primerov) zagovarjajo leksikografi, kot je AdamskaSalaciak (2006). Medtem ko so v slovarju Oxford takšni zgledi razdeljeni po pomenih (na voljo s klikom na gumb English example sentences; Slika 1), pa so v slovarju Collins podani na koncu gesla, skupaj z opozorilom, da so bili avtomatsko pridobljeni (navedena sta vir in leto objave). 


\section{house (1)}

casa, $n$. -(1))

Pronunciation /havs/ (?) A(s)) /havs/ ?? $4($ ))

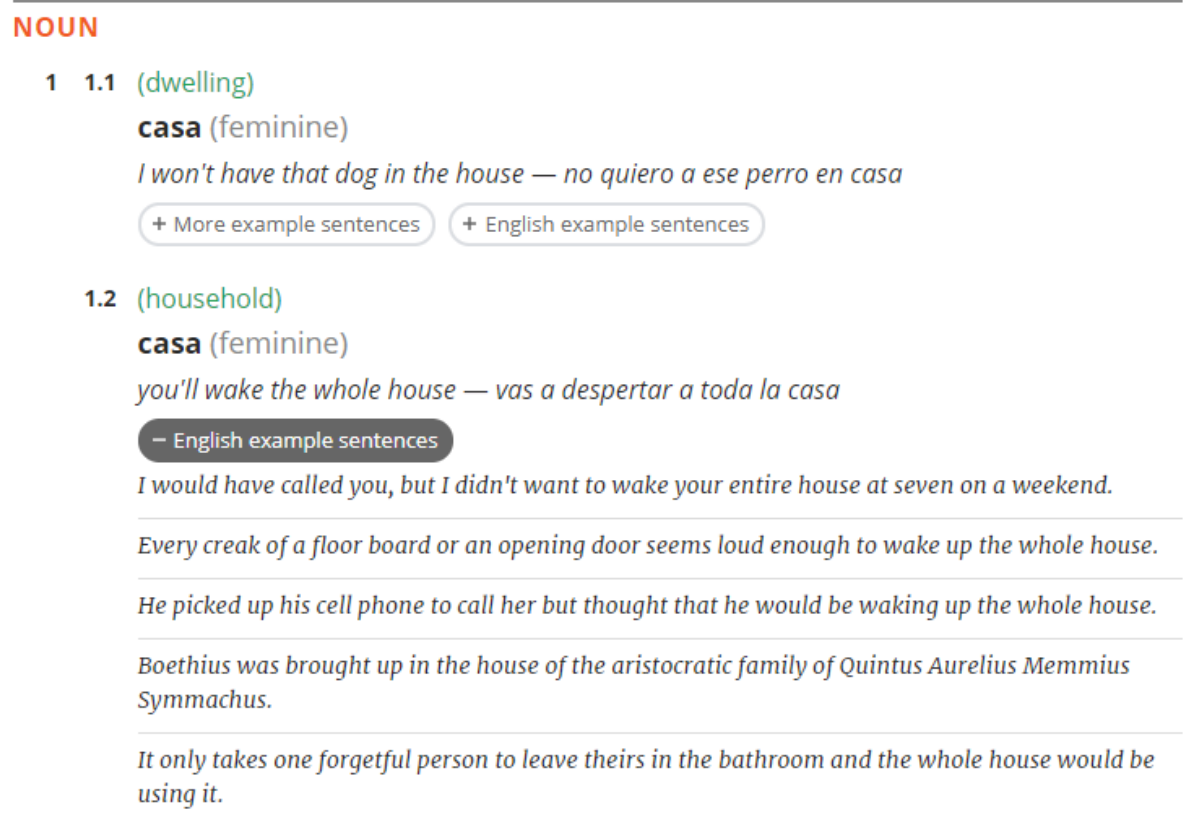

Slika 1: Dodatni zgledi rabe v angleško-španskem slovarju založbe Oxford.

- Podrobna členitev na pomene in podpomene. $\mathrm{V}$ tem pogledu je pomenska členitev bolj podobna enojezičnim slovarjem, iz katerih najbrž tudi izhaja. Vsakemu pomenu oz. podpomenu je dodan pomenski indikator, kar najdemo že v Hradilovih slovarjih, le da je v slovarjih Oxford in Collins raba doslednejša, slovar Collins pa tudi jasno nakaže tip indikatorja, npr. pred sinonimom ali kratko razlago je podan enačaj.

- Posnetki izgovorjav iztočnic, pa tudi glavnih prevedkov (slednjo informacijo ponuja samo slovar založbe Oxford).

- Podatki o spolu prevedkov. 
- Popolna odsotnost okrajšav. V geslih ni nobenih okrajšav, npr. za kvalifikatorje, podatke v zaglavju ipd. Izjema so le okrajšave za spol prevedkov v slovarju založbe Collins.

- Informacija o pogostosti iztočnice, ki jo najdemo v slovarju založbe Collins, in sicer pod razdelkom Trendi (angl. Trends), kjer sta podana opisni podatek, npr. da beseda house sodi med 1000 najpogostejših besed $\mathrm{v}$ angleškem jeziku, in graf, ki prikazuje gibanje pogostosti besede skozi stoletja (Slika 2).

- Slovar Collins ponuja povezave na gesla, npr. stalne zveze in ostale izraze, ki vsebujejo iztočnico.

- Slovar Collins ponuja tudi vsebine ostalih (dvojezičnih) virov, in sicer prevode iztočnice $v$ različne jezike.

\section{Trends of 'house'}

Extremely Common. house is one of the 1000 most commonly used words in the Collins dictionary

View usage for: All Years $\quad$

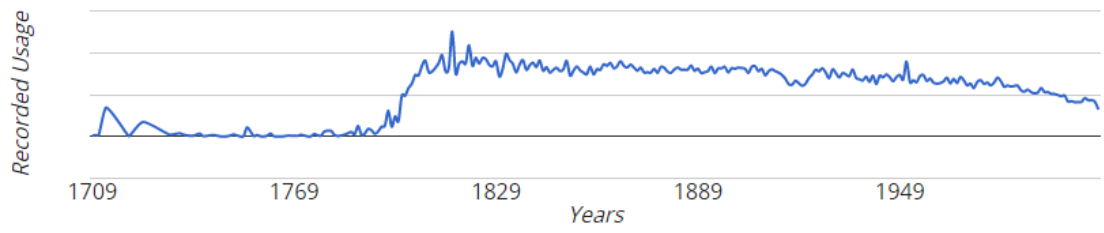

Slika 2: Razdelek z informacijo o pogostosti iztočnice v angleško-španskem slovarju Collins.

Z vidika inovativnega pristopa prikazovanja (avtomatsko pridobljenih) zgledov rabe velja omeniti še estonsko-finski in finsko-estonski slovar (Langemets idr. 2017), ki je trenutno v izdelavi. V njem bodo namreč uporabnikom na voljo neprevedeni zgledi tako v izvornem (estonščini) kot ciljnem jeziku (finščini), kar seveda poveča koristnost slovarja tudi za govorce izvornega jezika. 


\section{ZAKLJUČEK}

Prvi dvojezični slovensko-madžarski jezikovni viri so nastali pred več kot 200 leti, dvojezični slovarji večjega obsega pa pred nekaj več kot 50 leti. Slovarsko plodno je bilo predvsem obdobje ob koncu 20. stoletja, potem pa se je izdelava dvojezičnih slovensko-madžarskih in madžarsko-slovenskih slovarjev ustavila. Nov zagon izdelavi jezikovnih virov sta dala nedavna projekta E-kompetence učiteljev $v$ dvojezičnih šolah in KOMASS. Zlasti slednji je strogo slovarsko naravnan, in sicer na izdelavo koncepta novega Velikega slovenskomadžarskega slovarja, pri katerem je bil prvi korak pregled obstoječih dvojezičnih slovarjev za ta jezikovni par.

Opravljena primerjalna analiza treh slovensko-madžarskih slovarjev je pokazala, da je med tremi slovarji resda nekaj razlik, od katerih pa je vsekakor najopaznejše število gesel. Ostale razlike, kot sta npr. gnezdenje sicer legitimnih samostojnih iztočnic znotraj semantično povezanih iztočnic v BMSSMS95 in občasna različna obravnava homonimov ter način njihovega prikazovanja, so z vidika snovanja novega slovarja relevantne predvsem $\mathrm{v}$ tem, da se lahko prepoznajo dobre in slabe prakse.

Analiza e-zbirk izrazov kot najsodobnejšega slovensko-madžarskega jezikovnega vira je izpostavila, kako velik nabor besedišča mora pokrivati slovar, ki je namenjen učiteljem in učencem v dvojezičnem izobraževanju. Kot se je izkazalo, obstoječi slovensko-madžarski slovarji potreb teh uporabnikov trenutno ne morejo zadovoljiti $\mathrm{v}$ zadostni meri. Za projekt KOMASS je ta podatek pomemben zato, ker se kaže, da je pri snovanju Velikega slovenskomadžarskega slovarja smotrno razmišljati o vključevanju v slovarsko bazo podatkov, relevantnih za izobraževanje, ne pa o izdelavi samostojnega šolskega slovarja manjšega obsega.

Pregled izbranih dobrih praks na področju sodobne dvojezične leksikografije prikazuje po eni strani predvsem načine, kako izkoristiti potencial, ki ga za dvojezični slovar prinaša digitalni medij, po drugi strani pa bogatost vsebin, ki 
zadovoljijo različne tipe slovarskih uporabnikov. Pri tem smo izpostavili predvsem bogatost in strukturiranost ponazarjalnega gradiva ter inovativne pristope pri prikazovanju zgledov rabe. Poudariti velja tudi razmisleke o čim bolj uporabnikom prijaznih rešitvah, npr. izogibanje kraticam in jasno razločevanje pomenov.

Inovativni pristopi pri prikazovanju zgledov rabe izpostavljajo tudi manko dobrih in dovolj velikih vzporednih korpusov, ki so eden temeljnih virov za izdelavo sodobnih dvojezičnih slovarjev. Zlasti je malo vzporednih korpusov za jezikovne pare, ki ne vključujejo angleščine, kar velja tudi za par slovenščinamadžarščina.

Vseeno pa trenutno stanje na področju podpornih virov, predvsem enojezičnih, za slovenščino in madžarščino še zdaleč ni tako slabo. Na voljo imamo namreč sodobne referenčne korpuse (npr. korpus Gigafida), leksikone, jezikovnotehnološka orodja (označevalnike, razčlenjevalnike ipd.), govorne tehnologije ipd., pa tudi znanja, pridobljena na odmevnih projektih, kot je Veliki angleško-slovenski slovar Oxford-DZS, in metode, kot so avtomatsko luščenje leksikalnih podatkov (Gantar idr. 2016; Gorjanc idr. 2015). Pri projektu Velikega slovensko-madžarskega slovarja smo se združili jezikoslovci s takšnimi znanji, tako slovenski kot madžarski, kar bo pripomoglo k temu, da bo slovar predstavljal začetek novega pomembnega poglavja $\mathrm{v}$ sodobni dvojezični leksikografiji v Sloveniji.

\section{ZAHVALA}

Prispevek je nastal v okviru ciljno-raziskovalnega projekta Koncept madžarskoslovenskega slovarja: od jezikovnega vira do uporabnika (V6-1509), ki ga sofinancira Javna agencija za raziskovalno dejavnost Republike Slovenije iz državnega proračuna.

\section{LITERATURA}

Adamska-Salaciak, A. (2006): Translation of Dictionary Examples Notoriously Unreliable? In Proceedings of the 12th EURALEX 
International Congress: 493-501. Torino, Italy.

Bajec, A. idr. ur. (1991): Slovar slovenskega knjižnega jezika. Ljubljana: Založba ZRC, ZRC SAZU.

Bajzek Lukač, M. (2009): Slovar Gornjega Senika A-L. Maribor. Mednarodna založba Oddelka za slovanske jezike in književnosti, Filozofska fakulteta.

Bálint, J. (1997): Slovar slovenskih homonimov. Ljubljana. Znanstveni inštitut Filozofske fakultete.

Bálint Čeh, J. (2013): Okna v drugo kulturo - prevajanje kulturnospecifičnih izrazov v slovenskih literarnih prevodih. Hieronymus revija o prevajalstvu, 7 (1-2): 37-49.

Bernjak, E. (1995): Madžarsko-slovenski, Slovensko-madžarski slovar. Ljubljana. Cankarjeva Založba.

E-zbirke izrazov. http://eslovar.datadev.si/

$\begin{array}{llll}\text { Korpus } & \text { slovenskega } & \text { Gigafida. }\end{array}$

\section{http://www.slovenscina.eu/korpusi/gigafida}

Ftičar, J. (2006): Dramilo porabskih Slovencev ali njihov labodji spev? Ob prvem slovarju in prvem romanu v porabski slovenščini. Traditiones 35 (1): 159-166.

Gantar, P., Kosem, I., and Krek, S. (2016): Discovering Automated Lexicography: The Case of the Slovene Lexical Database. International Journal of Lexicography, 29 (2): 200-225.

Gorjanc, V., Gantar, P., Kosem, I. in Krek, S. ur. (2015): Slovar sodobne slovenščine: problemi in rešitve. Ljubljana: Univerza v Ljubljani, Filozofska fakulteta.

Hradil, J. (1982): Madžarsko-slovenski slovar z izbranim šolskim besediščem. Ljubljana. Budapest. Državna založba Slovenije. Tankönyvkiadó. 
Hradil, J. (1996): Slovensko-madžarski slovar. Ljubljana. Državna založba Slovenije.

Hradil, J. (1998): Madžarsko-slovenski slovar. Ljubljana. Pomurska založba.

Hradil, J. (2008): Sorsdöntő szavak. Szlovén-magyar irodalmi kapcsolatok. http://mta.hu/data/dokumentumok/szima/szekfoglalok/Hradil.pdf (dostop 7. 5. 2017).

Hradil, J. (2012): Slovensko-madžarski in madžarsko slovenski navzkrižni slovar. http://www.krog-znak-sp.si/slovensko.php/slo-hun-slovarszotar

Kališnik, M. ur. (1997): Pravopis medicinskih izrazov. Ljubljana: Medicinska fakulteta Univerze v Ljubljani.

Kozar, M. (1996): Etnološki slovar Slovencev na Madžarskem. Monošter. Szombathely. Savaria Múzeum. Zveza Slovencev na Madžarskem.

Krek, S. ur. (2005/2006): Veliki angleško-slovenski slovar OXFORD®-DZS. Ljubljana: DZS.

Krek, S. (2003): Sodobna dvojezična leksikografija. Jezik in slovstvo 1 (48): 456o. http://www.dlib.si/details/URN:NBN:SI:doc-LXQV6ETY (dostop 6. 11. 2017).

Langemets, M., Hein, I., Heinonen, T., Koppel, K. in Viks, Ü. (2017): From monolingual to bilingual dictionary: The case of semi-automated lexicography on the example of Estonian-Finnish dictionary. V: I. Kosem idr. (ur.): Proceedings of the 2017 eLex conference: Lexicography from Scratch. 19-21 September 2017, Leiden, Netherlands. Brno: Lexical Computing CZ s.r.o.

Logar Berginc, N., Grčar, M., Brakus, M., Erjavec, T., Arhar Holdt, Š. in Krek, S. 2012. Korpusi slovenskega jezika Gigafida, KRES, ccGigafida in ccKRES: gradnja, vsebina, uporaba. Ljubljana: Trojina, zavod za 
uporabno slovenistiko; Fakulteta za družbene vede.

Mukič, F. 1993. Madžarsko-slovenski frazeološki slovar. Szombathely. Zveza Slovencev na Madžarskem.

Mukič, F. 2005. Porabsko-knjižnoslovensko-madžarski slovar. Szombathely. Zveza Slovencev na Madžarskem.

Oxford dictionaries: https://es.oxforddictionaries.com/

Collins dictionary: https://www.collinsdictionary.com/

Šebjanič, F. (1961): Madžarsko-slovenski slovar. Ljubljana. Državna založba Slovenije.

Šebjanič, F. (1969): Slovensko-madžarski slovar. Ljubljana. Državna založba Slovenije.

Szalay, I., Košič, J. (prevajalec) (1833): Krátki návuk vogrszkoga jezika za zacsetníke.

Dostopno na: https://www.dlib.si/details/URN:NBN:SI:DOCKUVOB9JI.

Toporišič, J. idr. (1994): Slovenski pravopis 1 - Pravila. Ljubljana: ZRC SAZU.

Verbinc, F. (1991): Slovar tujk. Ljubljana: Cankarjeva založba.

Vidovič-Muha, A. 2000. Slovensko leksikalno pomenoslovje. Govorica slovarja. Ljubljana: Znanstvena založba Filozofske fakultete Univerze v Ljubljani. 
PRILOGA 1

\begin{tabular}{|c|c|c|}
\hline BMSSMS95 & SMS96 & eMASLO \\
\hline & $\begin{array}{l}\text { Bábilon } m \text { Babilon, } \\
\text { Bábel }\end{array}$ & $\begin{array}{l}\text { Babilon m Babilon, } \\
\text { Bábel }\end{array}$ \\
\hline $\begin{array}{l}\text { Balkán -a } m \text { Balkán(- } \\
\text { hegség) }\end{array}$ & Balkán $m$ geogr. balkán & Balkan m geogr. balkán \\
\hline \multicolumn{3}{|l|}{ Bált -a $m$ balti (ember) } \\
\hline Bált|ik -a $m$ Baltikum & Báltik $m$ geogr. Baltikum & Baltik m geogr. Baltikum \\
\hline \multicolumn{3}{|l|}{$\begin{array}{l}\text { Banát -a } m \text { Bánát; čan } \\
\text {-a } m \text { bánáti(ember) }\end{array}$} \\
\hline Básk a $m$ baszk(ember) & Básk a $m$ baszk & Bask m baszk \\
\hline \multicolumn{3}{|l|}{$\begin{array}{l}\text { Bavár|ska -e } \check{z} \\
\text { Bajorország; ec -rca } m \\
\text { bajor(ember) }\end{array}$} \\
\hline & $\begin{array}{l}\text { Bavárec } m \text { bajor } \\
\text { (ember) }\end{array}$ & $\begin{array}{lll}\text { Bavarec } & \mathbf{m} & \text { bajor } \\
\text { (ember) } & & \end{array}$ \\
\hline $\begin{array}{l}\text { Bélgij|a -e ž Belgium; } \\
\sim \text { ec -jca } m \text { belga(ember) }\end{array}$ & Bélgija $f$ Belgium & Belgija f Belgium \\
\hline \multirow[t]{2}{*}{$\begin{array}{l}\text { Belorús -a } m \\
\text { fehérorosz }\end{array}$} & $\begin{array}{l}\text { Belorús } m \text { fehérorosz, } \\
\text { belorusz }\end{array}$ & $\begin{array}{l}\text { Belorus m fehérorosz, } \\
\text { belorusz }\end{array}$ \\
\hline & $\begin{array}{l}\text { Belorúsija } f \text { geogr. } \\
\text { Fehéroroszország, } \\
\text { Belorusszia }\end{array}$ & $\begin{array}{l}\text { Belorusija f geogr. } \\
\text { Fehéroroszország, } \\
\text { Belorusszia }\end{array}$ \\
\hline $\begin{array}{l}\text { Beneč|án -a } m \\
\text { velencei(ember); íja -e } \\
\check{z} \text { Venetia }\end{array}$ & $\begin{array}{l}\text { Benečán } m \quad \text { velencei } \\
\text { (ember) }\end{array}$ & $\begin{array}{l}\text { Benečan m velencei } \\
\text { (ember) }\end{array}$ \\
\hline Benétke -nétkj ž (mn.) & & \\
\hline
\end{tabular}




\begin{tabular}{|c|c|c|}
\hline Velence & & \\
\hline $\begin{array}{l}\text { Bizantínec-nca } m \\
\text { bizánci(ember) }\end{array}$ & & \\
\hline-- & Bizánc $m$ Bizánc & Bizanc m Bizánc \\
\hline $\begin{array}{llr}\text { Bolgár } & \text {-a } & m \\
\text { bolgár(ember); íja } & \text {-e } \check{z} \\
\text { Bulgária } & & \end{array}$ & Bolgár $m$ bolgár & Bolgar $\mathbf{m}$ bolgár \\
\hline & $\begin{array}{l}\text { Bolgárija } f \quad \text { geogr. } \\
\text { Bulgária }\end{array}$ & $\begin{array}{l}\text { Bolgarija f geogr. } \\
\text { Bulgária }\end{array}$ \\
\hline & Bolívija $f$ Bolívia & Bolivija f Bolívia \\
\hline $\begin{array}{l}\text { Bosán|ec -nca } m \\
\text { bosnyák/ } \\
\text { boszniai(ember) }\end{array}$ & $\begin{array}{l}\text { Bosánec } m \text { bosnyák, } \\
\text { boszniai ember }\end{array}$ & $\begin{array}{l}\text { Bosanec m bosnyák, } \\
\text { boszniai ember }\end{array}$ \\
\hline-- & Bosánka $f$ bosnyák nő & Bosanka f bosnyák nő \\
\hline Bósna -e ž Bosznia & Bósna $f$ Bosznia & Bosna f Bosznia \\
\hline & Brazílec $m$ brazil (férfi) & Brazilec m brazil (férfi) \\
\hline $\begin{array}{l}\text { Brazíl|ija -e } \check{z} \text { Brazília; } \\
\sim \text { ec -lca } m \text { brazil(ember) }\end{array}$ & Brazílija $f$ geogr. Brazília & Brazilija f geogr. Brazília \\
\hline & Británec $m$ brit & Britanec $\mathbf{m}$ brit \\
\hline $\begin{array}{lccc}\text { Britán|ija } & \text {-e } & \check{z} \\
\text { Britannia; } & \sim \text { ec } & \text {-nca } & m \\
\text { brit(férfi) } & & & \end{array}$ & $\begin{array}{l}\text { Británija } f \quad \text { geogr. } \\
\text { Britannia; Velika } \\
\text { Nagy-Britannia }\end{array}$ & $\begin{array}{l}\text { Britanija f geogr. } \\
\text { Britannia; }(\text { Velika } \sim) \\
\text { Nagy-Britannia }\end{array}$ \\
\hline- & Búda $m$ Buddha & Buda m Buddha \\
\hline- & Búr $m$ búr & Bur m búr \\
\hline- & Burgúndija $f$ Burgundia & Burgundija f Burgundia \\
\hline- & Búrma $f$ geogr. Burma & Burma f geogr. Burma \\
\hline
\end{tabular}


Tabela 6: Zemljepisna lastna imena, ki se začnejo s črko B, v treh slovenskomadžarskih slovarjih.

\begin{tabular}{|c|c|c|}
\hline BMSSMS95 & SMS96 & eMASLO \\
\hline bacíl -a $m$ bacilus & bacíl $m$ med. bacilus & bacil m med. bacilus \\
\hline-- & $\begin{array}{l}\text { bacilonósec } m \text { med. } \\
\text { bacilushordozó, } \\
\text { bacilusgazda, vírusgazda }\end{array}$ & $\begin{array}{l}\text { bacilonosec m med. } \\
\text { bacilushordozó, } \\
\text { bacilusgazda, vírusgazda }\end{array}$ \\
\hline-- & $\begin{array}{l}\text { baktericíd } m \text { med., } \\
\text { farm. baktériumölő, } \\
\text { baktériumpusztító szer }\end{array}$ & $\begin{array}{l}\text { baktericid m med., } \\
\text { farm. baktériumölő, } \\
\text { baktériumpusztító szer }\end{array}$ \\
\hline-- & $\begin{array}{l}\text { baktericíden med., } \\
\text { farm. baktériumölő; i } \\
\text { učinek baktériumölő } \\
\text { hatás }\end{array}$ & $\begin{array}{l}\text { baktericiden med., } \\
\text { farm. baktériumölő; ( i } \\
\text { učinek) baktériumölő } \\
\text { hatás }\end{array}$ \\
\hline $\begin{array}{l}\text { Balt|ik -a } m \\
\text { Baltikum ; b ̌̌ki -a -o } \\
\text { balti; } \\
\text { Báltiško mórje } \\
\text { Balti-tenger }\end{array}$ & $\begin{array}{l}\text { baltiški geogr. Balti-; } \\
\text { Baltiško morje } \\
\text { Balti/Keleti-tenger }\end{array}$ & $\begin{array}{l}\text { baltiški geogr. Balti-; } \\
\text { (Baltiško morje) } \\
\text { Balti/Keleti-tenger }\end{array}$ \\
\hline-- & $\begin{array}{l}\text { balúster } m \text { arhit. } \\
\text { baluszter, korlátbáb, } \\
\text { mellvédbáb }\end{array}$ & $\begin{array}{l}\text { baluster m arhit. } \\
\text { baluszter, korlátbáb, } \\
\text { mellvédbáb }\end{array}$ \\
\hline-- & $\begin{array}{l}\text { balustráda } f \text { arhit. } \\
\text { balusztrád, bábos korlát }\end{array}$ & $\begin{array}{l}\text { balustrada f arhit. } \\
\text { balusztrád, bábos korlát }\end{array}$ \\
\hline-- & $\begin{array}{l}\text { banderóla } f \text { um. } \\
\text { banderole, mondatszalag }\end{array}$ & $\begin{array}{l}\text { banderola f um. } \\
\text { banderole, mondatszalag }\end{array}$ \\
\hline-- & $\begin{array}{l}\text { bántam } m \text { šport. } \\
\text { bantamsúly, harmatsúly }\end{array}$ & $\begin{array}{l}\text { bantam m (šport) } \\
\text { bantamsúly, harmatsúly }\end{array}$ \\
\hline-- & $\begin{array}{l}\text { bárhant } m \text { tex. barhent, } \\
\text { pamutszövet }\end{array}$ & $\begin{array}{l}\text { bárhant m tex. barhent, } \\
\text { pamutszövet }\end{array}$ \\
\hline
\end{tabular}




\begin{tabular}{|c|c|c|}
\hline-- & bárij $m$ kem. bárium & barij m kem. bárium \\
\hline-- & $\begin{array}{l}\text { barográf } m \text { meteor. } \\
\text { barográf }\end{array}$ & $\begin{array}{l}\text { barograf } \mathbf{m} \text { meteor. } \\
\text { barográf }\end{array}$ \\
\hline-- & bastión $m$ voj. bástya & bastion $\mathbf{m}$ voj. bástya \\
\hline-- & $\begin{array}{l}\text { bašibozúk } m \text { zgod. } \\
\text { basibozuk (régi törökök } \\
\text { szabadcsapat tagja) }\end{array}$ & $\begin{array}{l}\text { bašibozuk m zgod. } \\
\text { basibozuk (régi törökök } \\
\text { szabadcsapat tagja) }\end{array}$ \\
\hline $\begin{array}{l}\text { bateríja -e ž elem, } \\
\text { telep, üteg; mešalna } \\
\text { keverőelem; } \\
\text { oklópna páncélos } \\
\text { üteg; protiletálska } \\
\text { légvédelmi üteg; } \\
\text { žêpna } \\
\text { zseblámpaelem }\end{array}$ & $\begin{array}{l}\text { bateríja } f \text { 1. voj. üteg; } \\
\text { protiletalska } \\
\text { légvédelmi üteg; } \\
\text { poveljnik } \sim \\
\text { ütegparancsnok 2. fiz. } \\
\text { (lámpa)elem, } \\
\text { telepbattéria; za žepno } \\
\text { svetilko } \\
\text { (zseb)lámpaelem, kis } \\
\text { elem }\end{array}$ & $\begin{array}{l}\text { baterija f 1. voj. } \\
\text { üteg; (protiletalska ) } \\
\text { légvédelmi üteg; } \\
\text { (poveljnik }) \text { ) } \\
\text { ütegparancsnok 2. fiz. } \\
\text { (lámpa) elem, } \\
\text { telepbattéria; ( za žepno } \\
\text { svetilko) (zseb) } \\
\text { lámpaelem, kis elem }\end{array}$ \\
\hline-- & $\begin{array}{l}\text { bateríjski 1. voj. üteg-; } \\
\text { ogenj/streli ütegtúz } 2 . \\
\text { fiz. battéria, akkumulátor, } \\
\text { akkumulátoros, telep- }\end{array}$ & $\begin{array}{l}\text { baterijski 1. voj. üteg-; } \\
\text { ( ogenj/streli) ütegtüz } \\
\text { 2. fiz. battéria-, } \\
\text { akkumulátor, } \\
\text { akkumulátoros, telep- }\end{array}$ \\
\hline-- & $\begin{array}{l}\text { batisféra } f \text { teh. } \\
\text { batiszféra }\end{array}$ & $\begin{array}{l}\text { batisfera } f \text { teh. } \\
\text { batiszféra }\end{array}$ \\
\hline-- & batiskáf $f$ teh. batiszféra & batiskaf $\mathbf{f}$ teh. batiszféra \\
\hline $\begin{array}{l}\text { bazált -a m bazalt; } \\
\sim \text { en tna o } \\
\text { bazaltszerü, bazaltos }\end{array}$ & $\begin{array}{l}\text { bazálten petr. bazaltból } \\
\text { való, bazalt-; i rudnik } \\
\text { bazaltbánya }\end{array}$ & $\begin{array}{l}\text { bazalten petr. bazaltból } \\
\text { való, bazalt-; ( i rudnik) } \\
\text { bazaltbánya }\end{array}$ \\
\hline-- & $\begin{array}{l}\text { bázedovka } f \text { med. } \\
\text { bazedovkór }\end{array}$ & $\begin{array}{l}\text { bazedovka f med. } \\
\text { bazedovkór }\end{array}$ \\
\hline-- & $\begin{array}{l}\text { bazuka } f \text { voj. páncélököl, } \\
\text { tankelhárító fegyver; } \\
\text { bazooka }\end{array}$ & $\begin{array}{l}\text { bazuka f voj. } \\
\text { páncélököl, tankelhárító } \\
\text { fegyver; bazooka }\end{array}$ \\
\hline-- & $\begin{array}{l}\text { belemnít } m \text { geol. } \\
\text { belemnit }\end{array}$ & $\begin{array}{l}\text { belemnit m geol. } \\
\text { belemnit }\end{array}$ \\
\hline
\end{tabular}




\begin{tabular}{|c|c|c|}
\hline $\begin{array}{l}\text { beljakovína -e ž } \\
\text { fehérje }\end{array}$ & $\begin{array}{l}\text { beljakovína } f \text { kem., } \\
\text { med. fehérje, albumen }\end{array}$ & $\begin{array}{l}\text { beljakovina f kem., } \\
\text { med. fehérje, albumen }\end{array}$ \\
\hline-- & $\begin{array}{l}\text { belokŕvnost } f \text { med. } \\
\text { fehérvérüség, leukémia }\end{array}$ & $\begin{array}{l}\text { belokrvnost f med. } \\
\text { fehérvérüség, leukémia }\end{array}$ \\
\hline $\begin{array}{l}\text { belúš -a m spárga, } \\
\text { csirág }\end{array}$ & $\begin{array}{l}\text { belúš } m \text { bot. spárga, } \\
\text { csirág }\end{array}$ & $\begin{array}{l}\text { Beluš m bot. spárga, } \\
\text { csirág }\end{array}$ \\
\hline belúga -e ž (zoo.) víza & -- & -- \\
\hline $\begin{array}{l}\text { bèt -a } m \text { (bot.) torzsa, } \\
\text { buzogány }\end{array}$ & $\begin{array}{l}\text { bét } m \text { 1. (pri gobah) } \\
\text { tönk 2. fakalapács, } \\
\text { buzogány }\end{array}$ & $\begin{array}{l}\text { bet m 1. (pri gobah) } \\
\text { tönk 2. fakalapács, } \\
\text { buzogány }\end{array}$ \\
\hline $\begin{array}{l}\text { bóbnarica -e ž (zoo.) } \\
\text { bölömbika }\end{array}$ & -- & -- \\
\hline $\begin{array}{l}\text { bódež -a m (bot.) } \\
\text { tüske; szúrókés, tôr }\end{array}$ & -- & -- \\
\hline $\begin{array}{l}\text { bóljka -e ž (bot.) } \\
\text { borjúpázsit }\end{array}$ & -- & -- \\
\hline $\begin{array}{l}\text { brádlja -e ž (sp.) } \\
\text { korlát }\end{array}$ & $\begin{array}{l}\text { brádlja } f \text { 1. (telovadno } \\
\text { orodje) korlát } \mathbf{2 .} \\
\text { (tesarska sekira) bárd }\end{array}$ & $\begin{array}{l}\text { bradlja f 1. (telovadno } \\
\text { orodje) korlát } \mathbf{2} \\
\text { (tesarska sekira) bárd }\end{array}$ \\
\hline $\begin{array}{l}\text { brák -a } m(\mathrm{eb} .) \\
\text { rókakopó }\end{array}$ & -- & -- \\
\hline $\begin{array}{l}\text { brecílo -a s (anat.) } \\
\text { barlangostest }\end{array}$ & -- & -- \\
\hline $\begin{array}{l}\text { bréncelj -clja } m \\
\text { (zoo.) bagócs }\end{array}$ & bréncelj $m$ zoo. bögöly & brencelj m zoo. bögöly \\
\hline $\begin{array}{l}\text { brézovček -čka } m \\
\text { (zoo.) csíz }\end{array}$ & -- & -- \\
\hline $\begin{array}{l}\text { brezpálčnik -a } m \\
\text { (zoo.) gerezák, } \\
\text { kacskakezü majmok }\end{array}$ & -- & -- \\
\hline $\begin{array}{l}\text { bŕglez -a } m \text { (zoo.) } \\
\text { csuszka }\end{array}$ & bŕrglez $m$ zoo. csuszka & brglez m zoo. csuszka \\
\hline
\end{tabular}




\begin{tabular}{|l|l|l|}
\hline $\begin{array}{l}\text { bròč bróča } m \text { (bot.) } \\
\text { festóbuzér }\end{array}$ & -- & -- \\
\hline $\begin{array}{l}\text { bŕšček -čka } m \text { (bot.) } \\
\text { termetes medvetalp }\end{array}$ & -- & -- \\
\hline $\begin{array}{l}\text { bržóla -e ž } \text { (gasztr.) } \\
\text { rostélyos }\end{array}$ & $\begin{array}{l}\text { bržóla } f \text { sült és párolt } \\
\text { marhahús }\end{array}$ & $\begin{array}{l}\text { bržola f sült és párolt } \\
\text { marhahús }\end{array}$ \\
\hline $\begin{array}{l}\text { búba -e ž (zoo.) báb, } \\
\text { álca }\end{array}$ & $\begin{array}{l}\text { búba f zoo. báb, gubó; } ~ \\
\text { sviloprejke selyemgubó }\end{array}$ & $\begin{array}{l}\text { buba f zoo. báb, gubó; } \\
\text { ( sviloprejke) } \\
\text { selyemgubó }\end{array}$ \\
\hline $\begin{array}{l}\text { búrjevka } \text {-e ž (zoo.) } \\
\text { hajómadár }\end{array}$ & -- & -- \\
\hline
\end{tabular}

Tabela 7: Iztočnice od bacil do burjevka s terminološko oznako pod črko B v treh slovensko-madžarskih slovarjih. 


\section{THE FIRST STEPS TO A NEW COMPREHENSIVE SLOVENIAN-HUNGARIAN DICTIONARY: THE ANALYSIS OF RELEVANT BILINGUAL RESOURCES}

The paper presents the analysis of existing bilingual Slovenian-Hungarian dictionaries, which was made as part of the project aiming to design a concept for a new comprehensive Slovenian-Hungarian dictionary. First, a short historical overview of Slovenian-Hungarian lexicography is provided, including first collections of dialect vocabulary, glossaries, and collections and dictionaries of idioms. Then, an overview of Slovenian-Hungarian and Hungarian-Slovenian dictionaries is made, the first one being published in 1961.

The paper then focuses on a comparison on three Slovenian-Hungarian dictionaries, which are currently used by majority of users, namely SlovenianHungarian part of the dictionary by Elizabeta Bernjak (1995), SlovenianHungarian dictionary by Jože Hradil (1996), and Slovenian-Hungarian part of the Hradil's bidirectional dictionary. The dictionaries are compared in terms of size, headword list, coverage, headword presentation, grammar information, as well as in terms of other elements of dictionary microstructure such as translations and examples.

The discussion section includes an analysis of the coverage offered by the dictionaries of the vocabulary compilled by teachers at bilingual schools in Prekmurje. The results indicate that the coverage of various levels of vocabulary, frequent or rare, is rather poor; as dictionaries are medium-sized and outdated, this is to be expected, however as the analysis shows, some basic concepts are also often not covered (e.g. research, death, allergy).

The second part of the discussion is dedicated to the presentation of selected examples of good practice in bilingual lexicography, such as Comprehensive English-Slovenian dictionary Oxford-DZS as the first bilingual dictionary in Slovenia to use the corpus-based approach, as well as offer much more contextual 
information on the headwords. Also presented are English-Spanish online dictionaries by Oxford University Press and Collins, the focus being on the elements that demonstrate the utilization of the advantages of the digital medium.

Keywords: dictionary, Slovenian, Hungarian, bilingual lexicography, concept

To delo je ponujeno pod licenco Creative Commons: Priznanje avtorstvaDeljenje pod enakimi pogoji 4.o Mednarodna.

This work is licensed under the Creative Commons Attribution-ShareAlike 4.0 International.

https://creativecommons.org/licenses/by-sa/4.o/

(c) (i) () 